\title{
Agritourism - Sustainable Tourism Trend in Ben Tre Province, Vietnam
}

\author{
M.A. Phan Thi Ngan ${ }^{1}$ \\ ${ }^{1}$ The Faculty of Tourism and Vietnamese Studies, Nguyen Tat Thanh University, Ho Chi Minh City, Vietnam \\ Correspondence: M.A. Phan Thi Ngan, The Faculty of Tourism and Vietnamese Studies, Nguyen Tat Thanh \\ University, Ho Chi Minh CityVietnam E-mail: ptngan@ntt.edu.vn
}

Received: April 6, 2020; Accepted: April 25, 2020; Published: May 25, 2020

\begin{abstract}
Tourism and agriculture represent two of the world's largest economic industries. The combination of these two areas is critical to maximize the contribution of local tourism and economic development. Agri-tourism is an increasingly popular form of the tourism industry and may be soon one of the largest tourism sectors in a number of countries.

Agri-tourism is a suitable tool to balance the needs of tourists with the needs of rural communities, is a sustainable tourism trend that creates real opportunities for economic and social development and also minimizing undesirable impacts on the environment. Ben Tre with indigenous resources is very convenient to develop agricultural tourism. This will be a new livelihood option to both improve the rural economy and respond to the impacts of climate change on agriculture.
\end{abstract}

Keywords: Tourism, agritourism, sustainability, rural

\section{An Overview of Agritourism}

Agricultural tourism is also known as Agritourism or agrotourism. The two terms have the same meaning, but agritourism is more commonly used. Both of these terms have two parts: agri or agro + tourism. The agri prefix comes from the Latin term ager meaning field while agro comes from the Greek agros meaning soil and agronomos referring to the manager of the land property. The combination of the prefix agri with the noun tourism creates a new word that means human tourism for the purpose of becoming acquainted with agricultural and recreational activities in an agricultural environment. Agriculture tourism is a form of tourism in which tourists usually spend time on farms, plantations, and aquaculture zones (Note 1).

Despite a long history of development, the definition of agritourism remains unclear. The term agritourism is often replaced by rural tourism, farm tourism, green tourism or farm-based tourism (Note 2). Barbieri and Mshenga suggest that an activity developed on the farm for the purpose of attracting tourists is agricultural tourism. Meanwhile, Hegarty and Przezbórska emphasize not only activities on the farm, but also activities that take place off-farm in a rural context as agricultural tourism (Note 3). William and partners define agri-tourism as the combination of natural scenery and the products of agricultural activity incorporated into a travel experience. It offers visitors the opportunity to experience a wide range of different agricultural products and services (Note 5).

Similarly, Richard Sharpley and Julia Sharpley argue that agri-tourism is directly linked to the agro-environment, agro-products or farm stay (in a homestay or on a farm camp, and with educational tours, recreational activities, the sale of agricultural products or handicrafts). According to the two authors, agritourism is a broader concept than farm/farm-based tourism because it also includes festivals, museums, craft programs and cultural events, then agritourism is synonymous with rural tourism (Note 5). However, rural tourism is not a term synonymous with agricultural tourism. Agro-tourism is a subset of rural tourism because agriculture is the primary sector that shapes space and economic development in rural areas. These two terms are closely related. The difference between rural tourism and agricultural tourism lies in the nature of agricultural activities. First, agricultural tourism does not replace traditional agriculture. Therefore, it is essential for farm owners to pursue agricultural activities, not in favor of tourism, but to narrow down agricultural activities to replace them with tourism. Second, the nature of this form of tourism is rural and rural activities. In other word, the focus of agricultural tourism is to target specific activities in rural areas. The uniqueness of the agricultural tourism product includes four distinctive identities: the setting; tradition (traditional food, arts and culture); rural life and living with nature(Note 6). 
The term agritourism itself is understood differently by tourists and travel service providers. For tourists, agritourism means acquainted with agricultural production or leisure in an agricultural environment or an opportunity for visitors to experience the farm work during the excursion. In this sense, agritourism completely ignores the role of an agritourism provider while agritourism is a term introduced by supplier representatives describing the benefits of agriculture. This has resulted in a substantial expansion of the term agritourism to all activities related to service providers to tourists and restingers. Therefore, the person providing agricultural tourism services includes different forms of the term agritourism: agri-accommodation; the food and beverage industry - agri-food and beverages (agri-food); entertainment - agri-recreation (agricultural entertainment); relaxation - agri-relaxion (agricultural relaxation); sports - agrisport (agricultural sport) and even wellness and rehabilitation - agri-therapy (agricultural therapy) (Note 7). On that basis, S. Phillip, Colin Hunter, K. Blackstock in the article A typology for defining agritourism identified different types of agricultural tourism and classified them based on the level and method of visitor participation (Note 8).

The term agritourism, like many others, changes dramatically over time. However, definition clarification is needed to put agricultural tourism in its true dimension. Theodosia Anthopoulou and Yorgos Melissourgos have pointed out four key issues to define agricultural tourism: agricultural tourism as a 'product' (types of accommodation, activities, production, experience); business size and structure (concentrated small-scale operations, family cooperatives or community structures); stakeholders (local community, government) and impacts on rural communities. In short, agro-tourism is a form of tourism based on an agricultural economy that aims to generate tourism value through the local agricultural system. A form of tourism where visitors stay with locals in the countryside and spend their time on the farm, experiencing daily life and activities for entertainment purposes (Note 9).

In Agritourism's work, the group of researchers pointed out three attractive characteristics of agro-tourism. The first feature of agricultural tourism is for those who want to combine relaxation with learning more skills or experiencing life. It meets the needs of people who like to participate in the production labor process in the rural environment and immerse in the daily life of a peasant family. The second attraction is that agricultural tourism offers an opportunity to learn about the farmer's life, culture and customs. A third attractive feature of agro-tourism is its ability to respond to emotional needs through direct contact with animals, plant and animal products, processed products and the necessity of regional experience. The idyllic countryside is associated with the rustic atmosphere, tranquility, the sound or even the smell of the countryside and the farmland(Note 10).

Despite the controversy over the definition of agri-tourism, the impacts of agri-tourism on rural areas have been studied and verified through the economic, environmental and social sustainability of the rural areas.

\section{$>$ Sustainable economy}

Agro-tourism supports rural sustainability through capitalization of the rural environment by developing agricultural practices, improving infrastructure, and conserving local resources. Resources of this type of tourism are all that serve agricultural production. From means of production, land, rivers, lakes, people, production processes, farming practices, production products ... to natural factors related to agricultural production such as climate, weather... are all resource bases for agricultural tourism. Agro-tourism uses many resources from the rural environment to create agro-tourism products. Agricultural management experts point out that each farm essentially has free resources that are not used in the agricultural production process. Resources such as rooms, private food, free human resources, free space, and environmental resources such as scenery, clean air, rivers ... These resources can be used mainly during travel. As a result, they form the farm's natural tourism resource. When used, they provide the farmer with an additional source of income. The agro-tourism background is the belief that a farm is the primary entity providing tourism services. Having underutilized labor, housing, and cheap food, it can increase income through agricultural tourist activities. Agro-tourism is seen as a catalyst to preserve the viability and stability of rural areas with an emphasis on ecological agriculture, craftsmanship and tradition(Note 11).

Visitors to rural areas will spend money to participate in activities related to agriculture or buy byproducts. Tourism spending is not only related to agricultural tourism, but also related services in rural areas. Rural areas that exploit agri-tourism can trigger network externalities, encouraging additional commerce and services to form a circle of development. Agro-tourism activities in rural areas can create a new consumer market, increasing the average farmer's income through the sale of agricultural products and services to tourists, thereby ensuring sustainability of the agricultural sector(Note 12).

$>$ Environment sustainability 
Once farmers and rural communities have sustainable economic benefits from agricultural tourism development, environmental management issues such as water use, waste generation and energy use, the infection will be reviewed and resolved. Agricultural tourism will minimize the impact on the environment by reusing resources, recycling all useful materials, and reducing food waste.

Practicing eco-friendly agricultural tourism is key to attracting tourists. The role of agri-tourism activities in contributing to the creation and modification of rural landscapes. Farmers will strive to preserve the rural context: country life, peasant lifestyle, cuisine, protect native flora and fauna... to attract tourists to the farm. Agriculture towards clean, organic food can help protect the environment, making a difference as part of the big picture of conservation and responsible tourism.

\section{$>$ Sustainable Society}

Agricultural tourism offers employment opportunities especially for young people. Agri-tourism is a way to provide jobs for family members and the opportunity for the inheritance of traditional farming for future generations. Family farming's cross-generational continuity is a must in agribusiness. Agriculture combined with tourism is a great combination for farmers to continue working with farming, tending, maintaining and refreshing the farm. In addition, rural social sustainability will be ensured when agricultural tourism creates opportunities for underemployed people in rural areas to earn income in their place of residence, without having to flock to urban areas to make a living(Note 13).

The agricultural practices, festivals, craft villages, music, architecture, traditional cuisine... make each rural area special and unique. Agro-tourism programs help make use of the community's socio-cultural resources. In the opposite direction, the development of agricultural tourism will connect people with the local culture, preserve cultural heritages, encourage people to preserve and develop local traditional jobs for tourists and to admire, experience and shop for typical products where they visit. Agro-tourism not only creates jobs for farmers, but also develops new socio-cultural values. Agri-tourism connects farmers and urban dwellers, meeting visitors from different cultures will benefit rural children, while urban children will also have a deeper insight into the way live, rural people. Educational activities in agricultural tourism development bring new skills to the local community(Note 14).

\section{Agricultural Tourism in Ben Tre Province}

\subsection{Potential of Agricultural Tourism Resources:}

\section{* Natural Tourism Resource}

It is a coastal province at the end of the Mekong River, composed of 3 large islets such as Bao, Minh and An Hoa islets due to alluvium of 4 big tributaries, agglomeration of Tien and Ba Lai rivers, Ham Luong River and Co Chien River. Ben Tre have strengths in agricultural development and create strengths for agricultural tourism development. According to the Statistical Yearbook of Ben Tre 2019, agriculture and rural development is a very important sector for the socio-economic development of Ben Tre province, with a proportion of $35 \%$ of GRDP. The area of agricultural land accounts for about $75 \%$ of the natural area, agricultural labor in rural areas accounts for over $70 \%$ of the province's population(Note 15). Thanks to its abundant freshwater resources, Ben Tre is one of the provinces in the Mekong Delta with a highly developed agricultural and fishery sector. In addition to fresh water, with mangrove patches along the coast holds great ecological diversity of flora and fauna such as white hemp, white fish sauce, mangroves, dates, coconuts, mice, sea crabs, turtles, shrimps, cockles, snails... and especially storks. According to the Department of Agriculture and Rural Development of Ben Tre province, there are 98 types of fish, 18 types of shrimp and 2 types of clam, many of which have high economic and nutritional value such as squid, mackerel, tuna, lobster... Thanks to the endowment of natural resources, three types of sweet, brackish and salty ecology have been formed, creating a very diverse environment of animals, which is extremely potential for development of agricultural tourism in Ben Tre province.

Agriculture in Ben Tre is quite diverse because of a strategic combination of coconut trees, fruit trees, rice fields and aquaculture (especially shrimp farming) depending on the agro-ecological conditions of each region. In the northwest region, it is common for perennial fruit trees, especially in Chau Thanh and Cho Lach districts; bonsai in Cho Lach, coconut trees in Giong Trom, Mo Cay Bac and Mo Cay Nam. In this upstream area, alluvial soils dominate, making it the best soil for crop production. Therefore, crops of high economic value are cultivated in this area. In the midstream, salty alluvial soil and acid sulphate soils, coconut trees are popular crops. Rice is dominant in the downstream areas of Ba Tri and Thanh Phu districts where alluvial soils are salty and saline soils are the main soil type. Shrimp farming is concentrated in Binh Dai and Thanh Phu. 


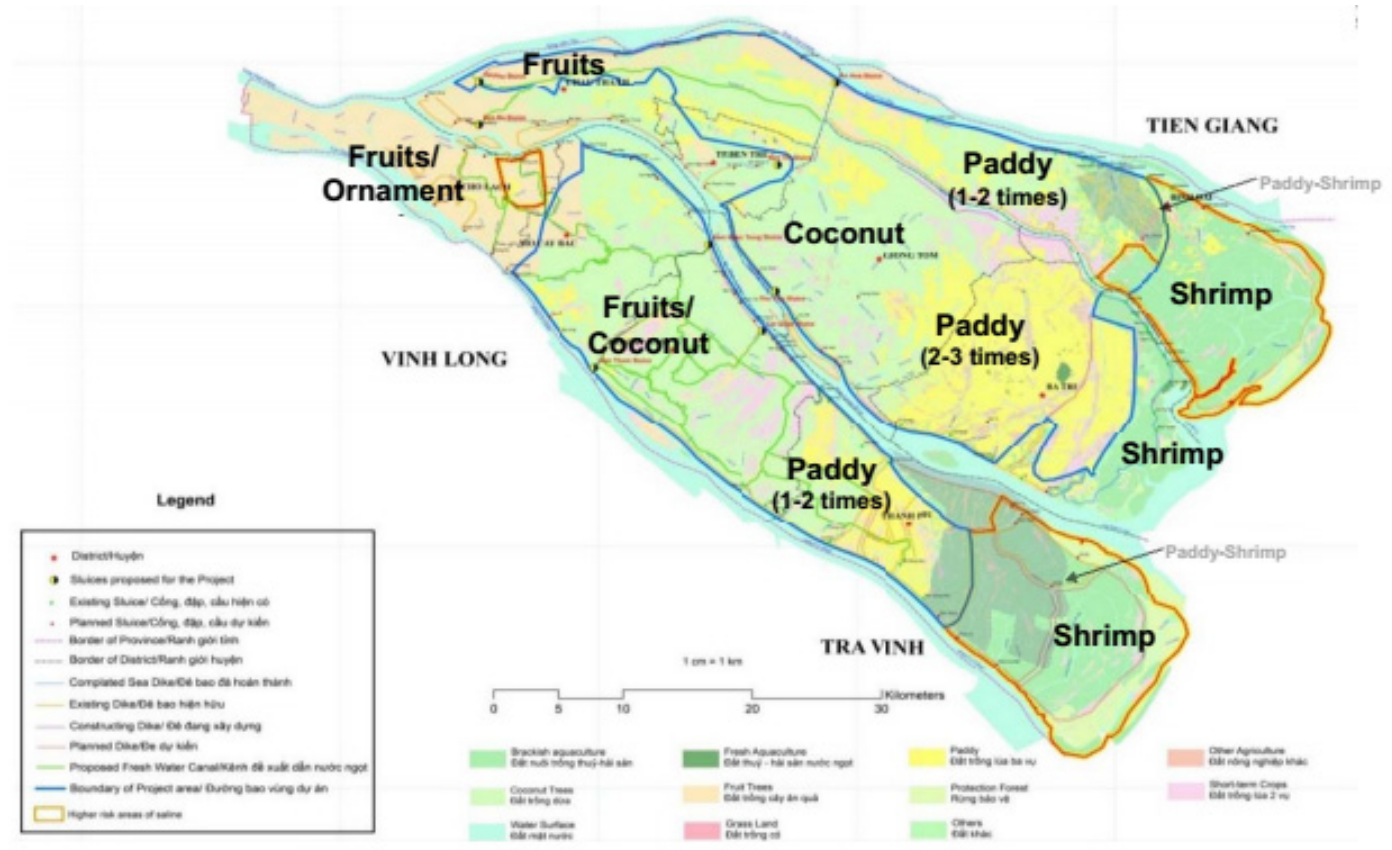

Figure 1. Phân bố vùng nông nghiệp tỉnh Bến Tre [Japan International Cooperation Agency, 2016, tr. 17]

Coconut garden ecosystem is built on the foundation of landscape, microclimate, creating sustainable development between farming economy and ecological stability. Currently, Ben Tre province is implementing a restructuring in the field of cultivation. The crops with low economic value such as rice, sugarcane have gradually decreased to switch to coconut and high value fruit and vegetable crops. In order to meet the increasing product quality requirements, Ben Tre increases the organic coconut area (the two districts with the largest coconut growing areas are Giong Trom and Mo Cay Nam), towards specialized cultivation towards biosafety, GAP standards, serving the needs of domestic consumption and export, combining with tourism development(Note 16).

Vam Ho bird sanctuary is a typical ecosystem for mangrove forests along the Mekong estuary. The special attraction of Vam Ho bird sanctuary lies in the natural landscape of the river and the rich flora and fauna. The nature reserve also has a gardening agricultural ecosystem specializing in growing fruit trees. Assessing the prospects for development of tourism, natural reserves with potential for ecotourism development as well as agricultural tourism models (survey results $46.7 \%$ rated very positive, $30 \%$ rated positive) (Note 17).

\section{* Human resources associated with agricultural tourism}

Banh Trang My Long and Banh Phong Son Doc are two traditional villages of Ben Tre that are recognized as national intangible cultural heritages. Banh Trang My Long has a history of hundreds of years associated with the previous small market of this land. In the specific birth history, no one knows "just knowing that just a toddler... stumbled across piles of rice paper in the house, when growing up, he will continue his career and career". Currently, Banh Trang My Long village, Giong Trom district has about 150 bakeries, there are households that are generation 2 and 3 making this. People are skillful in making Banh Trang My Long. They are real artisans. The characteristic feature of Banh Trang My Long that attracts visitors is the cake made from sticky rice and thick coconut milk, so it is both fat and spongy. Banh Phong Son Doc also existed for hundreds of years in Hung Nhuong commune, Giong Trom district. The village of Banh Phong Son Doc currently has about 30 establishments producing banh chung. Banh Phong Son Doc is made from waxy sticky rice, flexible, fragrant. The cake is characterized by a thick coconut water scent. The cake maker must be a skilled person, otherwise the cake will not be of quality, so the puff cake is the crystallization of the ingenuity, creativity, the baker's whole heart blends with the treasure that nature bestowed on the land of coconut. Banh Trang My Long and Banh Phong Son Doc are the pride of coconut people(Note 18).

In the rural area of Ben Tre province, there are more than 100 enterprises operating in coconut production: canned coconut water, coconut milk, coconut candy, activated carbon, refined coconut oil, refined cooking oil, cosmetics... All parts from coconut trees can be used to produce souvenirs to create unique characteristics of Ben Tre. Only coconut wood, coconut shell has more than hundreds of handicraft items. Coconut shaped 12 zodiac, orchids, bird's 
nest... Coconut tree is used to arrange flowers, decorate the guest table, welcome gate at events. Coconut rubbing is combined into flower baskets, decorative lanterns. Coir is used to make carpets of many shapes. Coconut root is also made of unique handicrafts. Especially coconut painting, an art item that is very popular with foreign tourists. This is a unique work created from parts of the coconut tree such as shells, fibers, leaves, and stems that have undergone elaborate process showing the skillful hands of artisans. Some typical traditional craft villages such as: the Hung Phong coconut basket weaving village (Giong Trom district), the Phuoc Long coconut basket weaving village (Giong Trom district), the My An coconut broom craft village (Thanh Phu district) Lien Thanh Company (Mo Cay Nam District), Luc Quan Minh Campus (Ben Tre City), Thanh My Facility (Ben Tre City), Thanh Binh Campus (Chau Thanh District), Thanh Campus Liem (Mo Cay Nam district)...

Ben Tre is also known as the "kingdom of ornamental flowers and seedlings". The whole province has 33 craft villages producing ornamental flowers and seedlings, of which Cai Mon is the largest craft village in Vietnam. Products of seedlings, ornamental bonsai, ornamental and flowers are consumed throughout Vietnam and exported to Korea, China, and Taiwan. The profession of producing seedlings - ornamental flowers of Cai Mon and Cho Lach has a long history since the end of the eighteenth century by priest Phan Van Minh and scholar Truong Vinh Ky when traveling to Southeast Asian countries to bring the seedlings and to guide the people to plant. The gardens here gradually became famous and spread since then. Every year, on the occasion of the Dragon Festival, the fruit festival of Cho Lach takes place, many gardeners inside and outside the province participate, this is also an opportunity for visitors to come and visit. The production of seedlings and ornamental flowers not only creates jobs for people but also creates a unique identity of the village. The handicraft villages of Cho Lach have large, airy space, fresh air, and many fruit tree products, which is a highlight to attract visitors.

In terms of religious activities, the custom of worshiping Thanh Hoang is the belief of farming residents, the place of worship is the communal house. In Ben Tre, village communal house was born associated with the process of reclaiming and opening a village. Communal house often associated with Ky Yen festival. The festival is an opportunity for people to make offerings to express their gratitude to the gods and also to be an opportunity for people to gather for community entertainment activities. Worshiping whales (Ong fish) is the belief of sea fishermen. It is associated with the Nghinh Ong festival that is held annually in the three districts of Ba Tri, Binh Dai and Thanh Phu. In addition, the folk beliefs, spirituality from the story of Dao Dua - Nguyen Thanh Nam, the pilgrimage of followers of Cao Dai Tien Thien to the Central Dao, Thanh Chau Minh, are also factors that need to be considered in strategy to mobilize people's participation in tourism development in the long term.

With Eastern cultural traditions, the living environment, the intersection of ethnic cultures and the history of the festival's development are very rich and diverse. The festival is an opportunity to pay homage to all kindness, merit to the country, to the people, pray for good rain, good wind, a warm and happy people. Some major festivals in Ben Tre province such as: communal worship festival, Dong Khoi festival, especially the festivals associated with agriculture such as the Coconut Festival, the fruit festival on the 5th of lunar May - Doan Ngo festival, Nghinh Ong Festival... Coconut Festival is a festival with national scale attracting many domestic and foreign tourists. Through the Coconut Festival activities, visitors will have a better understanding of the cultural identity of Ben Tre. The festival is chaired by the Provincial People's Committee and the Ben Tre Department of Culture, Sports and Tourism in coordination with the Vietnam Craft Villages Association (VICRAFTS) is organized, with the sponsorship of the Ministry of Industry and Trade, the Ministry of Culture, Sports and Tourism. Coconut Festival has been held 5 times in 2009, 2010, 2012, 2015 and 2019. The successful organization of coconut festivals has created a highlight for the land of Ben Tre. Ong Binh Thang festival, Binh Dai district is recognized as the national intangible cultural heritage. This is the first national intangible cultural heritage in Ben Tre. Nghinh Ong Nam Hai festival is a typical festival of the coastal fishing community held on June 16 of the lunar calendar every year in the coastal villages of Binh Dai district, Ba Tri district, Thanh Phu district. In particular, the Nghinh Ong festival in Binh Thang commune attracts many tourists from inside and outside the province to visit and participate in the festival.

Ben Tre is the land that still preserves and develops the typical folk performing arts of the Southern region such as Hat Boi, Cai Luong. Hat Boi is a form of traditional performing art widely popular in Ben Tre in the midnineteenth century. Ben Tre's professional troupe Hat Boi was born in the early years of the twentieth century. In recent years, Hat Boi in Ben Tre began to recover, and Hat Boi in the communal houses was held more often. The inclusion of Hat Boi in communal village events, peaceful festivals and tourism both preserves traditional culture and attracts visitors, especially foreign visitors to learn about the national cultural identity. Don ca Tai Tu is a feature of the Southern region. Particularly in Ben Tre, the Don Ca Tai Tu movement not only thrives in tourist areas, but also becomes a regular club in the villages. The combination of Don $\mathrm{Ca} \mathrm{Tai} \mathrm{Tu}$ and garden cuisine creates an attraction for domestic and foreign tourists. Concerning the two types of Hat Boi and Cai Luong, the 
festival music has also developed extensively on 3 Ben Tre islets. From official ceremonial music, to Tai Tu music, and from Tai Tu music borne Tai Tu. In Ben Tre, two verses of festival music are handed down:

\author{
"Ben Tre has four Dong Den \\ Sa Ken, Hau Trong, Do Co, Mo Cong"
}

These four musicians are masters of the province. As of 2013, the whole province had 87 ceremony bands with 312 musicians; Some units have many bands and musicians such as: Ben Tre city, Chau Thanh district, Ba Tri, Mo Cay Nam. Ben Tre ceremonial music groups are used in ceremonial - marriage - funeral - ritual ceremonies such as serving at communal rest ceremonies, parades, shrine rites and in funerals to help preserve identity and handed down a unique folk performing art form of Ben Tre. Ben Tre has many activities to maintain the type of music festival such as organizing the Ben Tre Provincial Music Festival periodically.

Singing Sac Bua is a popular folk performing art form in the North, North and Central region and South Central region. In the South, singing Sac Bua is only available in Phu Le commune, Ba Tri district. Singing Sac Bua Phu Le is derived from singing Sac Bua in Southern Central and can be directly derived from singing Sac Bua Nghia Binh. Singing Sac Bua Phu Le is a folk cultural activity of an agricultural ceremonial nature mixed with Taoist magic that takes place on the occasion of the Lunar New Year or to worship the communal house every year. The movement of singing Sac Bua Phu Le in Ben Tre is increasingly developing and gradually forming many singing teams contributing to the unique feature of the cultural treasure of land of Coconut. On January 23, 2017, singing Sac Bua Phu Le was officially recognized as the National Intangible Cultural Heritage.

Ben Tre has available tourism resources to develop agri-culinary tourism products that are different from other localities in the Mekong Delta. Ben Tre is known as "the land of Vietnam Coconut" not only because of the largest coconut plantation area but also because of the culture and culinary arts associated with the coconut tree for a long time. The dishes made from coconut are a unique feature that creates the image of Ben Tre destination. Doan Thi My Hanh in the article Creating the destination image "Coconut Country" with culinary tourism products has summarized there are 22 salty dishes, 27 sweet dishes and 4 drinks using coconut ingredients. From the list of 53 basic dishes, the people of Ben Tre also process them into version dishes. Especially in the culinary list, if the famous lam rice of the Northwestern people, coconut rice is the sweet dish flavor of Ben Tre homeland. Coconut rice is the rice cooked in a coconut, the rice seeds soaked in coconut water will be steamed until they are dry, so the sweet rice seeds are fragrant. Coconuts are often chosen for cooking as sapodilla.

Coconut wine is a unique specialty of Ben Tre. This is not only a refreshing drink but also a healthy medicine. One of the new products that has been researched and produced is wine from bottled fermented aged coconut water. Recently, to serve the tastes of tourists, people have used rice wine to put in old coconut with rice or put in fresh coconut milk to make coconut wine. Above all, however, coconut nectar wine is the most noted for its nutritional value. Coconut nectar is taken from coconut flower (coconut flower), coconut nectar is taken as palm nectar. This is a very fragrant and cool water flowing from the coconut flower. Because coconut nectar is about $15 \%$ sugar, the wine coconut nectar is fermented completely naturally by the nectar of coconut nectar, giving sweet taste and very pleasant aroma. In 2007, Dong Go Coconut Center, Ben Tre under the Oil and Oil Research Institute, initially researched and explored the process of collecting coconut nectar with an average yield of 30 liters/flowering, each flowering can extraction within 30 days. On each coconut tree, it is possible to exploit nectar for two consecutive flowering. In 2010, the Oil and Oil Plants Research Institute successfully accepted the ministerial-level project "Research on using nectar of coconut tree for high sugar and alcohol production". Experimental results have built the process of wine production from coconut nectar (scale 20 liters/batch). The process of producing coconut wine, if applied widely, can make a difference for agricultural tourism in Ben Tre compared to the western provinces.

Experimental research results show that the impression of tourists' destination when arriving in Ben Tre is affected by factors of safe tourism environment, interesting attractions, beautiful natural scenery, climate, pleasant, affordable for travel and affordable with $95 \%$ reliability. Tourists said they were very impressed with the cuisine in Ben Tre province, especially the foods made from coconut products, creating a memorable taste for visitors.

\title{
2.2. Sustainable Trends in the Context of Climate Change
}

The Mekong Delta is vulnerable to climate change such as severe flooding in the rainy season and saline intrusion in the dry season caused by sea level rise. Ben Tre farmers rely on water from rivers for irrigation. These tributaries are located southeast of Ben Tre, which is why this area is one of the areas most affected by saline intrusion in Vietnam under the influence of climate change. The damage caused by saline intrusion will be more and more widespread and serious in Ben Tre. The high salinity level is expected to cause serious damage not only to the rice fields in the central region but also extensive fruit farms in the upstream area. Damage of Ben Tre is the highest 
estimate among the 7 coastal provinces due to saline intrusion based on JICA study (Note 19). Survey results of the research on model building research: "Tourism farmers" implemented in 2020 in Ben Tre showed that the climate change situation increasingly affects production and human life only $24.3 \%$ of the population, the number of people who are not or less affected; the number of people affected, affected more or less is more than $75 \%$.

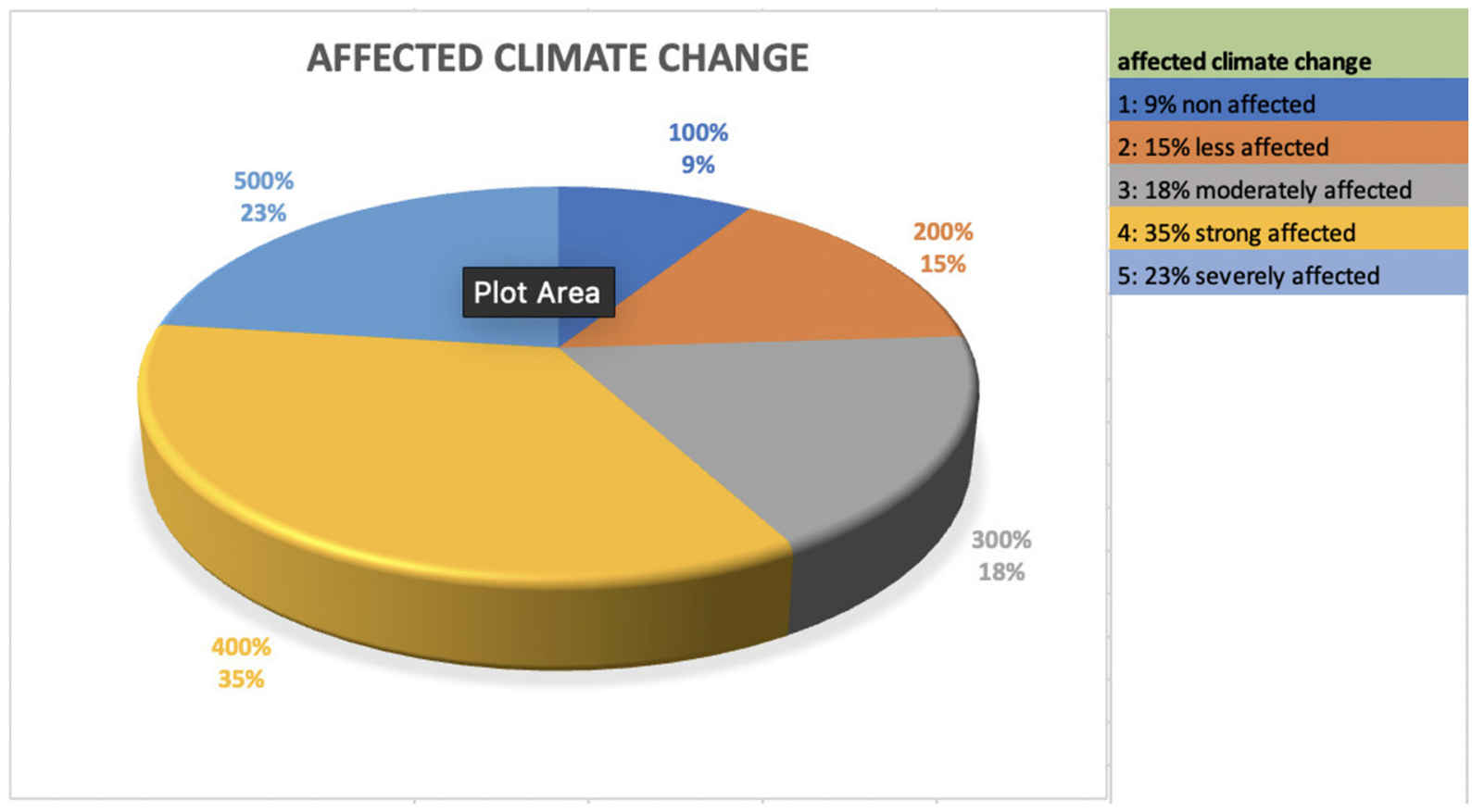

Figure 2.

Source: Affected climate change situation in Ben Tre

According to a report from the General Statistics Office of Vietnam, the per capita income of Ben Tre province in 2019 is 3,685 million VND/month, ranked 31/63 provinces and cities nationwide and 9/13 provinces in the Mekong Delta. Long. The average income per capita of Ben Tre is less than 45 million/person/year. With the advantages of agricultural potential, but the farmer's income is too low, it shows that only doing the agricultural economy does not guarantee the lives of people in Ben Tre, it is necessary to have a new sustainable livelihood plan long term for the farmer.

Sustainability is the most notable topic in the current rural economic development in Ben Tre under pressure from climate change concerns and environmental issues. Sustainable development can be seen as achieving the most relevant social, economic and environmental nexus. Aim to maximize all three types of benefits as much as possible but there is a need for a balance between them. Therefore a sustainable approach would be to seek a solution that maximizes all three benefits. In general, however, one implies that economic benefits are long-term rather than short-term and do not have to be sacrificed for social and environmental benefits. It can be seen that an important aspect of sustainability in development in Ben Tre is the sustainability of peasant society from the benefits of agribusiness in the rural environment. From the reality of rural areas in Ben Tre, agricultural tourism development is one of the solutions with dual benefits to promote the construction of a new countryside, to form a service economy in rural areas, livelihoods for farmers, contributing to preserving and promoting traditional cultural values, landscape and ecological environment, and backing the support for the diversified and sustainable development of tourist destinations.

\section{Conclusion}

The development of agricultural tourism is not only suitable for prevention and handling of climate change situations, but also very important in the economic development of the locality, ensuring the implementation of the green development strategy and effective response to climate change. Agricultural tourism is a form of rural tourism, a specialized type of tourism (niche tourism) with activities taking place mainly on farms in rural areas. Agro-tourism can link the economic, social and environmental components of sustainability, a strategy that can be seen as creating and diversifying for farms. Agricultural tourism development brings income, landscape, economic 
development of tourism, conservation to increase livelihoods for people while bringing spiritual, material values, community connection. Ben Tre province, with potential for indigenous tourism, has also made steps to develop rural tourism in association with agriculture. River garden tours system: 76 tourist sites; 27 homestay areas are concentrated in communes along Tien river. In 2018, reaching 840,000 visitors, up $30 \%$ over the same period, revenue reached 676 billion. Ben Tre Homestay attracts $35-40 \%$ of the visitors from the European market. With the available advantages, promoting agricultural tourism in rural areas will be a suitable and sustainable direction of Ben Tre province.

\section{References}

Barbieri, C., \& Mshenga, M. (2008). The role of the firm and owner characteristics on the performance of agritourism farms. Sociologia Ruralis, 48. https://doi.org/10.1111/j.1467-9523.2008.00450.x

Doan Thi My Hanh (2019), Creating an image of the destination "Coconut Country" with culinary tourism products, Lac Hong Science Journal, 6.

Hegarty, C., \& Przezbórska, L. (2005). Rural and agri-tourism as a tool for reorganising rural areas in old and new member states - a comparison study of Ireland and Poland, International Journal of Tourism Research, 7(2). https://doi.org/10.1002/jtr.513

Japan International Cooperation Agency. (2016). The preparatory survey for Ben Tre water management project.

Kalyan Mandi et al., (2019). Agro Tourism: Exploring New Avenues In Rural India, Science for Agriculture and Allied Sector, 1(1).

Khoi Nguyen (2021). Banh Trang My Long, Banh Phong Son Doc, Vietnam Craft Village Magazine, No. 6-8.

Maria, G. P., Alessandra, F., \& Neil, R. (2020). Agritourism, Wine Tourism, and Craft Beer Tourism: Local Responses to Peripherality Through Tourism Niches, Routledge.

Michał, S., Lucyna, P., \& Frank, S. (2009). Agritourism, CAB.

Ministry of Culture, Sports and Tourism. (2019). Project "Rural tourism development associated with building a new countryside".

Neda, Tiraieyari \& Azimi, H. (2012). Agri-tourism: Potential opportunities for farmers and local communities in Malaysia, African Journal of Agricultural Research, 7(31). https://doi.org/10.5897/AJARx11.035

Ngo, An, Phan Thanh Au, \& Nguyen Thi Diem Tuyet (2018). Development strategy of ecotourism in Ben Tre bird sanctuary nature reserve until 2022, Van Hien University Journal of Science, 6(2). https://doi.org/10.47800/PVJ.2021.02-02

Nguyen Hoang Anh (2020). Analysis of the implementation of agricultural restructuring in Ben Tre province towards increasing added value and sustainable development. Industry and Trade Journal, 12.

Nguyen Thi Thuy \& fellow workers (2010). Study on the use of nectar from coconut tree for high sugar and alcohol production. Summary report for the topic at Ministry level.

Nguyen Van Dinh, Cao Thi Sen \& Nguyen Thi Lua (2019). Solutions to develop coconut products in Ben Tre. Journal of Science and Development Economics, 7.

People's Committee of Ben Tre Province (2018). Ben Tre - Potential and investment opportunities, Publisher Thong Tan.

Pham Hong Thai (2020). Factors affecting international tourist satisfaction and intention to return to destination: case study of Ben Tre province. Journal of Science, Tra Vinh University, 37. https://doi.org/10.35382/18594816.1.37.2020.372

Recep Efe, \& Münir Öztürk (2014). Tourism, Environment and Ecology in the Mediterranean Region, Cambridge.

Richard Sharpley \& Julia Sharpley (1997). Rural Tourism: An Introduction, International Thomson Business.

S. Phillip, Colin Hunter, K. Blackstock, 2010, A typology for defining agritourism. Tourism Management, 31. https://doi.org/10.1016/j.tourman.2009.08.001

Tomás F. Espino-Rodríguez (2019). Sustainable Directions in Tourism, MDPI.

\section{Notes}

Note 1. Michał Sznajder, Lucyna Przezbórska \& Frank Scrimgeour, 2009, Agritourism, CAB, tr. 3 
Note 2. C. Barbieri, M. Mshenga, 2008, The role of the firm and owner characteristics on the performance of agritourism farms, Sociologia Ruralis, vol 48, tr. 168

Note 3. C. Hegarty, L. Przezbórska, 2005, Rural and agri-tourism as a tool for reorganising rural areas in old and new member states - a comparison study of Ireland and Poland, International Journal of Tourism Research, 7 (2), tr. 63-77

Note 4. Kalyan Mandi et al., 2019, Agro Tourism: Exploring New Avenues In Rural India, Science for Agriculture and Allied Sector, vol 1 (1), tr. 10

Note 5. Richard Sharpley, Julia Sharpley, 1997, Rural Tourism: An Introduction, International Thomson Business, tr. 9

Note 6. Tomás F. Espino-Rodríguez, 2019, Sustainable Directions in Tourism, MDPI, tr. 101

Note 7. Michał Sznajder, Lucyna Przezbórska \& Frank Scrimgeour, 2009, sđd, tr. 3 - 4

Note 8. S. Phillip, Colin Hunter, K. Blackstock, 2010, A typology for defining agritourism, Tourism Management, vol 31, tr. $754-758$

Note 9. Maria Giulia Pezzi, Alessandra Faggian, Neil Reid, 2020, Agritourism, Wine Tourism, and Craft Beer Tourism: Local Responses to Peripherality Through Tourism Niches, Routledge, tr.4

Note 10. Michał Sznajder, Lucyna Przezbórska \& Frank Scrimgeour, 2009, sđd, tr.7

Note 11. Michał Sznajder, Lucyna Przezbórska \& Frank Scrimgeour, 2009, sđd, tr. 4

Note 12. Recep Efe, Münir Öztürk, 2014, Tourism, Environment and Ecology in the Mediterranean Region, Cambridge, tr.244

Note 13. Tomás F. Espino-Rodríguez, 2019, sđd, tr. 103

Note 14. Neda Tiraieyari and Azimi Hamzah, 2012, Agri-tourism: Potential opportunities for farmers and local communities in Malaysia, African Journal of Agricultural Research, 7(31), tr. 4359

Note 15. Nguyễn Hoàng Anh, 2020, Phân tích tình hình thực hiện tái cơ cấu ngành nông nghiệp tỉnh Bến Tre theo hướng nâng cao giá trị gia tăng và phát triển bền vững, Tạp chí Công thương, số 12, http://tapchicongthuong.vn/bai-viet/phan-tich-tinh-hinh-thuc-hien-tai-co-cau-nganh-nong-nghiep-tinh-ben-tretheo-huong-nang-cao-gia-tri-gia-tang-va-phat-trien-ben-vung-73531.htm

Note 16. http://tapchicongthuong.vn/bai-viet/phan-tich-tinh-hinh-thuc-hien-tai-co-cau-nganh-nong-nghiep-tinhben-tre-theo-huong-nang-cao-gia-tri-gia-tang-va-phat-trien-ben-vung-73531.htm

Note 17. Ngô An, Phan Thanh Âu, Nguyễn Thị Diễm Tuyết, 2018, Chiến lược phát triển du lịch sinh thái ở khu bảo tồn thiên nhiên sân chim vàm hồ tỉnh bến tre đến năm 2022, Van Hien University Journal Of Science, vol. 6 , N. 2 , tr. $87-89$

Note 18. Khôi Nguyên, 2021, Làng nghề bánh tráng Mỹ Lồng, bánh phồng Sơn Đốc, Tạp chí Làng nghề Việt Nam, số 6-8, tr.16

Note 19. Japan International Cooperation Agency, 2016, The preparatory survey for Ben Tre water management project, tr.1

\section{Copyrights}

Copyright for this article is retained by the author(s), with first publication rights granted to the journal.

This is an open-access article distributed under the terms and conditions of the Creative Commons Attribution license (http://creativecommons.org/licenses/by/4.0/). 